University of Montana

ScholarWorks at University of Montana

$1-1969$

\title{
The Influence of Information Signs on Visitor Distribution and Use
}

Perry J. Brown

University of Montana - Missoula, perry.brown@umontana.edu

John D. Hunt

Utah State University

Follow this and additional works at: https://scholarworks.umt.edu/forest_pubs

Part of the Forest Management Commons

Let us know how access to this document benefits you.

\section{Recommended Citation}

Brown, Perry J. and Hunt, John D., "The Influence of Information Signs on Visitor Distribution and Use" (1969). Forest Management Faculty Publications. 39.

https://scholarworks.umt.edu/forest_pubs/39

This Article is brought to you for free and open access by the Forest Management at ScholarWorks at University of Montana. It has been accepted for inclusion in Forest Management Faculty Publications by an authorized administrator of ScholarWorks at University of Montana. For more information, please contact scholarworks@mso.umt.edu. 


\section{The Influence of Information Signs on Visitor Distribution and Use}

\section{by Perry J. Brown and John D. Hunt}

Lack of information is a primary factor accounting for visitors jamming recreation sites, overflowing onto highway rights-of-way and blocking facilities [5, p. 95]. In attempting to attain an even distribution of visitors, the importance of information signing as a management tool is often overlooked.

Oxenfeldt indicates that advertising (information) alters behavior most efficiently when it supplies information customers are seeking [4, p. 471]. Tocher and Kearns noted in visitor characteristic studies that travelers seek different experiences when touring than when at home or work [6]. Information signs may lead the visitor to these different experiences.

Hypothesizing that signs can influence facility use patterns, researchers at Utah State University in 1964 and 1965 conducted a visitor use and motivation study in the Logan Canyon Recreation Complex, Utah. (The original study from which portions of these data were obtained was initiated by S. Ross Tocher, Instructor, University of Michigan while he was a member of the College of Natural Resources Faculty at Utah State University.) This report focuses on two questions: (1) do information signs help distribute visitors more evenly? and (2) do information signs stimulate greater use of a previously unsigned roadside rest area?

\section{Distribution Between Two Sites}

One phase of the study was conducted to determine if it would be possible to stimulate visitors to use a lightly used reststop (Canteen Spring) rather than a heavily used reststop (Ricks Spring).

Ricks Spring roadside rest area is highly developed in comparison to Canteen Spring. The Ricks Spring site included drinking facilities, a lavatory, a historical interpretive sign and a large, bubbling spring. In contrast, Canteen Spring had only a water fountain, fenced area and little or no maintenance. Except during peak holiday hours, there is adequate parking at both areas to handle present use.

\section{Sampling Methods}

Because of differing parking arrangements, a different sampling method was used at each of the reststops to determine the percentage of vehicles stopping. Ricks Spring has a long parking space on both sides of the highway; Canteen Spring parking is on only one side of the highway.

Perry J. Brown is lecturer, and John D. Hunt is chairman, Institute for the Study of Outdoor Recreation Tourism, Utah State University, Logan, Utah. 
Sampling was conducted every day during two one-week periods in the summers of 1964 and 1965. During these sample periods personal observations were made of the vehicles stopping at Ricks Spring between $8 \mathrm{am}$. and $8 \mathrm{pm}$. The total number of vehicles passing through the area were recorded on a pneumatic traffic counter. New tallies and counter readings were taken every hour.

Vehicles stopping at Canteen Spring were recorded by these traffic counters: one hose across the highway to record total traffic flow, and a second hose across the parking area to count every stopping vehicle. The counters were read at least once per day.

In addition, counts were made at less frequent intervals from June to September at the two rest areas, and the counters were checked repeatedly for accuracy.

As a control, data were collected for one week at both rest areas before sign changes were made. For the second week, "Drinking Water Ahead" signs were erected along the highway above and below Canteen Spring.

Efforts were made to identify and eliminate the effect of variables other than signing treatment on comparable days. Because the two sites are located within the same considered minor because of the close proximity of the two study sites. Temperature and other weather effects were also minimized by conducting observations of the control and signing treatment on comparable days. Because the two sites are located within the same closed recreation complex, other external factors appear to be less important than might otherwise be the case. Also, by expressing results as averages of many observations, the extremes that may have been influenced by radical changes in external variables were negated. The primary test of reliability, however, was the repetition of results over two succeeding years.

\section{Vehicle Stoppage}

Study results indicated a significant change in vehicle stoppage attributable to the signs (Fig. 1). In both study years, a change significant at the .95 probability level was observed in the percentage of vehicles stopping at Canteen Spring. ${ }^{*}$ Since the percentage increase at Canteen Spring was much greater than the percentage decrease at Ricks Spring, it was inferred that the signs promoted visitations by some people who would not have stopped. In addition, the reduction in Ricks Spring use could likely be attributed to the increased use of Canteen Spring, thus suggesting that a more even distribution of visitor use between the two roadside reststops was achieved.

Observations and limited research in retail stores suggest that the above inferences are sound. Agnew claims that people do very little thinking for themselves. When they are told to do something, they do it without asking why $[1, \mathrm{p} .330]$. This is probably true as long as what is asked of a person does not run counter to that person's fixed beliefs and experiences. It is likely that most short information signing does not violate this one criterion.

*The necessary Chi-square for significance at the .95 probability level is 3.84 , at one degree of freedom. 1964 difference $X^{2}=41.3 ; 1965$ difference $X^{2}=19.4$. 


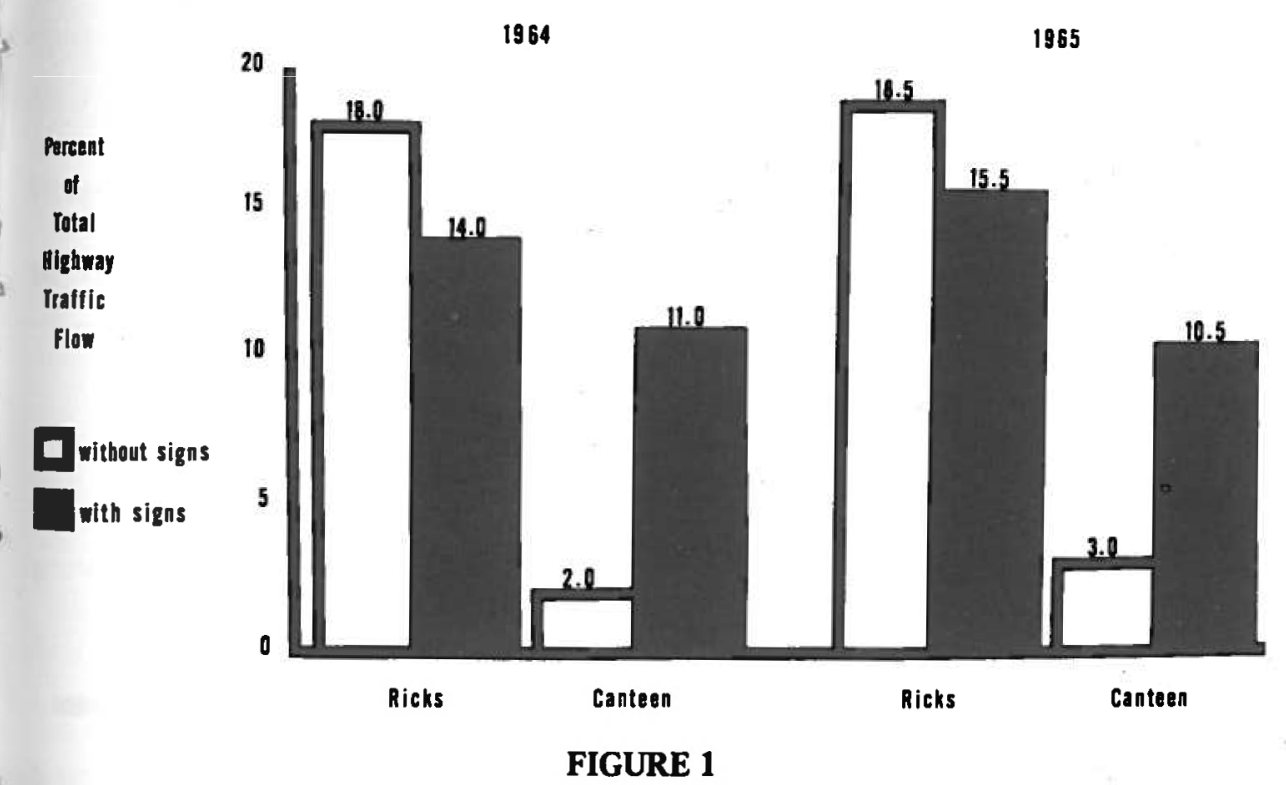

Average Percent of Total Traffic Stopping by Year at Ricks Spring and Canteen Spring, Logan Canyon, Utah, 1964 and 1965.

Also, there are indications that in-store posters help direct store traffic flows. For example, posters on main floors influence customers to visit upper floors, and posters in one department encourage shoppers toward other departments [2, p. 380].

\section{Stimulation of Use}

The stimulation of use phase of the study was conducted to determine if simple information signs would stimulate greater stoppage at Ricks Spring. For example, one study of point-of-purchase displays in grocery stores indicates that displays with information signs increased sales over normal shelf sales about twice as much as displays without information signs [3, p. 322].

The same signs used in the distribution phase were used in the stimulation phase. The signs were attached to existing road signs (rectangular, white on green, metal) for Ricks Spring. The new combination of signs read, "Ricks Spring" and just below "Drinking Water Ahead." The sampling method was that described previously for Ricks Spring in the distribution phase of the study.

Again, consideration was directed toward the elimination of variables other than signing. Observations of the control and signing treatment were taken on days of comparable weather and only averages were recorded to reduce any radical variable 


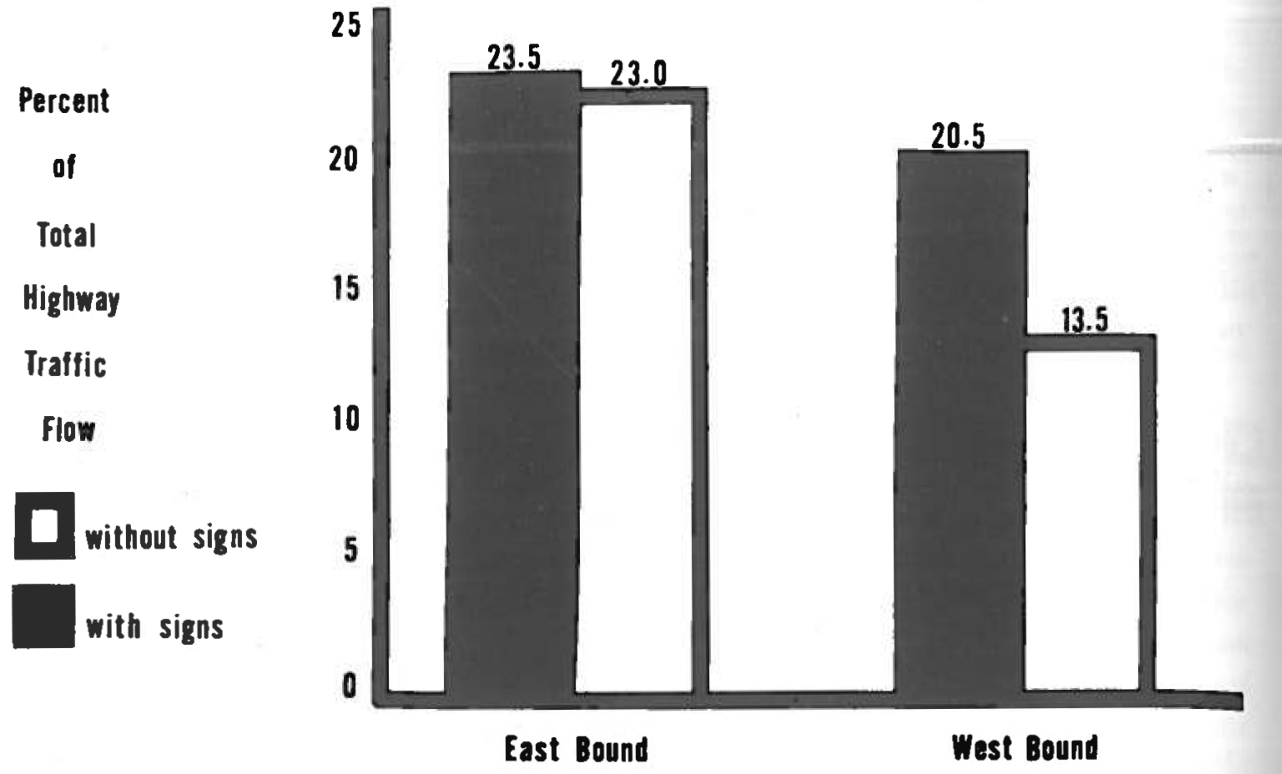

\section{FIGURE 2}

Average Percent of Total Traffic Stopping by Direction of Travel, Ricks Spring, Logan Canyon, Utah, 1965.

effects. Although the experiment was not repeated there is little evidence to indicate that changes in external variables coincided with the placement of signs.

Upon erection of signs an appreciable increase in stopping by westbound vehicles was noted (13.5 percent as compared to 20.5 percent; see Figure 2).* However, signs had little effect on increasing the stopping by eastbound vehicles.

The reststop approach may be responsible for the lack of a significant increase in the percentage stopping of eastbound vehicles. The approach from the west is made along a long straight section of highway, and signing may have little significance since visitors can already see the activity at the site.

The approach from the east is the opposite. Westbound traffic arrives at the reststop with little advanced knowledge of its location because of a curve in the highway. Advance notice of the site may give the visitor time to stop.

Preparing the visitor for what is ahead appears to be one value of signing in situations like Ricks Spring. Conversely, removal of existing signs may reduce use.

*The necessary Chi-square for significance at the .95 probability level is 3.84 , at one degree of freedom, and this increase is significant: $\mathrm{X}^{2}=\mathbf{4 . 2 0}$. 


\section{Conclusions}

Information signs are instrumental in distributing use more evenly between roadside reststops and in stimulating additional travelers to stop at the facilities. Also, they prepare visitors to stop and take advantage of facilities.

Information signing, though often overlooked, may be an important tool for the resource manager in achieving desired control of visitor movements.

\section{References}

1. Agnew, Hugh E., Advertising Media, New York: D. Van Nostrand Company, Inc., 1932, Pp. 426.

2. Edwards, Charles M., Jr. and Howard, William H., Retail Advertising and Sales Promotion, Revised Edition, New York: Prentice-Hall, Inc., 1945, Pp. 723.

3. Hapner, Harry W., Effective Advertising, New York: McGraw-Hill Book Company, Inc., 1941, Pp. 548.

4. Oxenfeldt, Alfred R., Executive Action In Marketing, Belmont, California: Wadsworth Publishing Company, Inc., 1966, Pp. 799.

5. Tocher, S. Ross and Hunt, J.D., "Recreation Research: A Quest for Essential Knowledge," Utah Science, Utah Agricultural Experiment Station, Vol. XXV, No. 4, (December 1964), p. 95.

6. Tocher, S. Ross and Kearns, F.W., "Intercepting the Tourist," Utah Science, Utah Agricultural Experiment Station, Vol. XXII, No. 4, (December 1962), p. 127. 